\title{
Development of story calendar media: Literacy resources for learning of narrative writing skills and character responsibilities
}

\author{
Tri Astuti Rokhmani *, Suhardi Suhardi \\ Universitas Negeri Yogyakarta. Jl. Colombo No. 1, Karangmalang, Yogyakarta 55281, Indonesia \\ * Corresponding Author. E-mail: jesi.alexander@lecturer.unri.ac.id
}

Received: 5 December 2020; Revised: 2 April 2021; Accepted: 2 May 2021

\begin{abstract}
This research is motivated by the need for instructional media to improve narrative writing skills and the character of student responsibility. Because of this, a story calendar with the theme of responsibility was developed. This research is $\mathrm{RnD}$ research. Starting from research and information collecting, planning, develop a preliminary form of product, preliminary field testing, main product revision, main field testing, operational product revision. Based on the media development results that have been performed above, it can be concluded that the story calendar media are ready for implementation. The validity is proven by the validators, consisting of the media expert, material expert, language expert, and the teachers and students' responses. The mean score from the expert and teachers responses is belongs to "Very Eligible" criteria. All the student's responses showed that they said "Yes" almost 100\% in all the statements from the student's questionnaire. It is expected that the story calendar media can serve as an alternative of literacy media and supplementation learning material, especially for writing skills learning and developing student's responsibility character.
\end{abstract}

Keywords: media, story calendar, writing skill, narrative, responsibility

How to Cite: Rokhmani, T., \& Suhardi, S. (2021). Development of story calendar media: Literacy resources for learning of narrative writing skills and character responsibilities. Jurnal Prima Edukasia, 9(2), 202-212. doi:https://doi.org/10.21831/jpe.v9i2.36315

\section{Introduction}

The literacy ability of students in the 21 st century is closely related to the demands of reading skills that lead to the ability to understand information analytically, critically, and reflectively. Literacy skills are manifested in various activities at school. Literacy activities in schools include developing language skills.

Language skills include six things, including listening, speaking, reading, writing, seeing and interpreting visual displays (Rachman et al., 2020; Tompkins, 2015). The six skills in the curriculum at school are only known for four skills, namely listening, speaking, reading, and writing narratives. Johnson (2008) states that the four language skills work together and are interrelated. This shows that each skill is related to other skills. These skills show an orderly sequence. Initially, a person learns to listen, then speaks, and only after mastering these skills can learn to read and write.

Ahn (2012) argues that writing is often considered one of the most challenging aspects because the writer must understand the linguistic features of different types of text. Based on some of the opinions, writing is often considered a difficult language skill. Ambarwati and Budiningsih (2018) also say that writing is a very complex process. Before writing their stories, students should plan, for example, the topic, layout and organization of their ideas. When they express their ideas, several aspects must be considered in relation to language; for example, the formation of students' words, diction, and sentences must be organized in an effective manner. Furthermore, the student's spelling and punctuation must be done properly and functionally. This process is proof that writing skills are indeed very complex.

Therefore, we need media that can help students learn to write. One of the alternative media is story calendar media (USAID/Indonesia, 2014). The purpose of story calendar media is to motivate students to read and write because every page has a relationship. Besides that, the story calendar media can be a way to develop the student's character through the story in it. Because of that, the story calendar media development is needed. Therefore, this research aims to develop an eligible story calendar media 
Jurnal Prima Edukasia, 9 (2), 2021 - 203

Tri Astuti Rokhmani, Suhardi Suhardi

based on expert judgment (media, material, and language) based on teacher and student responses questionnaire during field testing in schools.

\section{Methods}

The design of this study was the Research and Development $(\mathrm{RnD})$ proposed by Borg and Gall (1983). The research stages include: (1) Research and information collecting, (2) Planning, (3) Develop a preliminary form of product, (4) Preliminary field testing; (5) Main product revision, 6) Main field testing, (7) Operational product revision, (8) Operational field testing, (9) Final product revision, and 10) Dissemination and implementation. In this article, we will present the results up to stage 7 , namely operational product revision.

The research was carried out in July-November 2020 in 5 public elementary schools in Srandakan District, Bantul, Yogyakarta. The subjects involved in this study were one media expert, one material expert, and 1 linguist for product assessment by experts. The initial field test involved 9 grade IV students and 1 grade IV teacher from SD Negeri 2 Srandakan. Furthermore, the field trial subjects were 18 grade IV students and 2 grade IV teachers from SD Negeri 1 Srandakan (Grades A and B).

For product assessment data collection by experts, researchers used a product rating scale instrument. Meanwhile, to find out the teacher's response to the media using the teacher response scale instrument and for students using student response questionnaires. The data obtained in the form of scores were converted to determine the feasibility level of the media and were analyzed descriptively.

Analysis of product feasibility data was obtained from product assessment scale data by experts (media, material, and language), and from teacher, response scale data was carried out by adding up the scores obtained on each indicator. After adding up, the descriptions per indicator were divided so that the mean was obtained. The mean score is in the form of quantitative data, which is then converted into qualitative data according to the conversion guidelines. Thus, a category is obtained if the mean score is $\leq 1.8$ to very good if the mean is $>4.2$ (Widoyoko, 2015). Guidelines for scale conversion and product feasibility as written in the Table 1 .

Table 1. Conversion and Product Eligibility Criteria

\begin{tabular}{clcc}
\hline Score & \multicolumn{1}{c}{ Score interval (Quantitative) } & Mean & Criteria (Qualitative) \\
\hline 5 & $\mathrm{X}>\overline{\mathrm{X}}_{\mathrm{i}}+1,80 \mathrm{SB}_{\mathrm{i}}$ & $>4,2$. & Very Eligible \\
4 & $\overline{\mathrm{X}}_{\mathrm{i}}+0,60 \mathrm{SB}_{\mathrm{i}}<\mathrm{X} \leq \overline{\mathrm{X}}_{\mathrm{i}}+1,80 \mathrm{SB}_{\mathrm{i}}$ & $>3,4-4,2$ & Eligible \\
3 & $\overline{\mathrm{X}}_{\mathrm{i}}-0,60 \mathrm{SB}_{\mathrm{i}}<\mathrm{X} \leq \overline{\mathrm{X}}_{\mathrm{i}}+0,60 \mathrm{SB}_{\mathrm{i}}$ & $>2,6-3,4$ & Eligible Enough \\
2 & $\overline{\mathrm{X}}_{\mathrm{i}}-1,80 \mathrm{SB}_{\mathrm{i}}<\mathrm{X} \leq \overline{\mathrm{X}}_{\mathrm{i}}-0,60 \mathrm{SB}_{\mathrm{i}}$ & $>1,8-2,6$ & Less Eligible \\
1 & $\mathrm{X}<\overline{\mathrm{X}}_{\mathrm{i}}-1,80 \mathrm{SB}_{\mathrm{i}}$ & $\leq 1,8$ & Not Eligible \\
\hline
\end{tabular}

Very Eligible $=$ VE; Eligible $=$ E; Eligible Enough $=$ EE; Less Eligible $=$ LE; Not Eligible $=\mathrm{NE}$

The story calendar media is considered eligible if it gets a minimum score of 4 with the criteria of "Eligible".

\section{Result and Discussion}

Research dan Information Collecting

The preliminary study stage was carried out through interviews, a questionnaire on needs analysis for teachers and students, and a literature study. The questionnaire of the needs analysis was carried out with 4 grade IV teachers and 74 fourth grade students from SD Negeri Godegan, SD Negeri 1 Srandakan, and SD Negeri Gunungsaren. Meanwhile, interviews were conducted with 4 grade IV teachers and 6 grade IV students.

Based on questionnaires and interviews, data on three things were obtained, namely a description of narrative writing skills, the character of student responsibility, and the needs of story calendar media. The problems in students' narrative writing skills are (1) difficulty finding and pouring story ideas; (2) difficulty starting writing stories; (3) not understanding the elements of narrative composition, (4) repetition of sentences in stories; (5) less coherent writing of stories; and (6) limited vocabulary. Meanwhile, the difficulties faced by the teacher were: (1) limited supporting learning media; (2) limited teaching time for students to write narratives.

The character of student responsibility also needs to be improved. The problems encountered, namely: (1) not doing assignments on time; (2) not carrying out pickets; (3) helping parents, not because 
Jurnal Prima Edukasia, 9 (2), 2021 - 204

Tri Astuti Rokhmani, Suhardi Suhardi

of their awareness; (4) not implementing health protocols consistently during the pandemic; (5) underestimating the duties of the teacher. The teacher feels that the media used to develop the character of student responsibility is still lacking, and the character of students is different, so it needs consistency and continuous efforts.

Thus, the development of story calendar media to improve narrative writing skills and character responsibility is needed. This is also due to the lack of variety in the available learning media and the unavailability of story calendar media. The results of this preliminary study are used as the basis for developing a story calendar media to improve narrative writing skills and character responsibility for fourth-grade elementary school students.

Planning

The research planning stage of the story calendar media development includes some activities. The first is formulating research objectives, namely developing a story calendar media to improve narrative writing skills and the character of responsibility for fourth-grade students of public elementary schools in Srandakan Bantul. After that, analyzing Core Competencies (KI), themes, sub-themes, Basic Competencies (KD), and formulating indicators to be achieved according to the 2013 curriculum for grade IV SD. The third step is to identify and formulate indicators of narrative writing skills for fourthgrade elementary school students. And then identify and formulate indicators of character responsibility for fourth-grade elementary school students. Focused Group Discussion (FGD) is also done with fourthgrade elementary school teachers, friends, media experts, linguists, and material experts to gather input regarding the story calendar media that will be developed.

Develop Preliminary Form of Product

The initial product development stage was carried out by designing a story calendar media design including the format, story content, instructions for use, assignments, and initial product development into a story calendar. According to the selected theme, the designs are arranged in the form of an image design and story content, namely responsibility.

The stories presented in this media are narrative essays. In this case, the story is structured in such a way as to be close to the child's world and contextual, namely by taking the theme of responsibility in the Covid-19 pandemic situation. The title of this media is Kalender Cerita Hebatnya Bertanggung Jawab.

Making illustrations asks for the help of an experienced illustrator in making illustration drawings for children's storybooks or fairy tales. As for the preparation of the media layout, it asked a layout design expert from the printer.

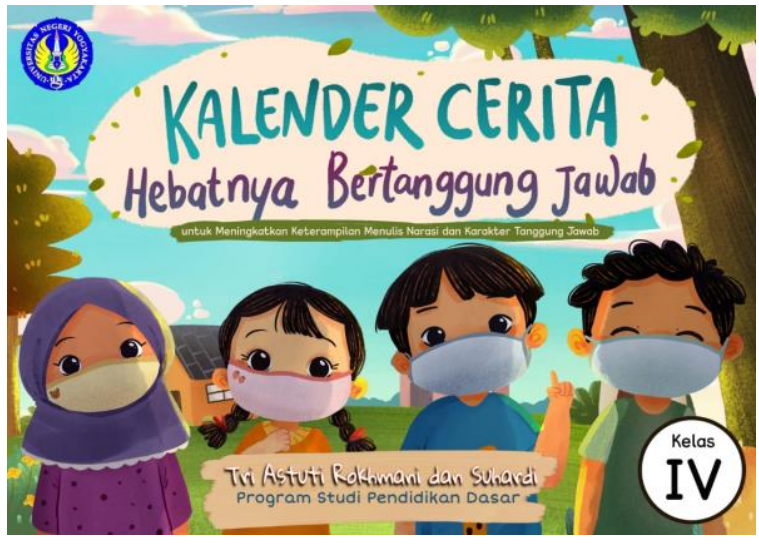

Figure 1. Cover of Story Calendar Media

The picture above showed the cover of story calendar media. The title is Kalender Cerita Hebatnya Bertanggung Jawab. Bertanggung Jawab means responsibility. There are four children on the cover. They are the story figures in the story calendar media. They are Arini, Safira, Damar, and Bima. They used a mask to represent that the story in it was composed in the context of Covid-19 and linked to the character of responsibility. The story presented is made up of a narrative story.

After the initial product has been made, the product is printed according to the initial concept, namely in the form of a spiral calendar with A3 size for teachers and A4 size in a sitting calendar for 
students. The media was printed on Ivory 260 paper. The next process was testing the product validation by media experts, material experts, and linguists. The results of product validation tests to experts are described below.

Product Validation Test by Media Experts

Media experts validate the initial product of the story calendar media to determine the feasibility level of media quality from media experts. The following page displays a table of the results of the product rating scale by media experts.

Table 2. Results of Product Assessment by Media Experts

\begin{tabular}{|c|c|c|c|c|}
\hline No. & Aspects & Indicators & Mean Score & Criteria \\
\hline \multirow[t]{2}{*}{1.} & Consistency & Spacing and letters & 5 & VE \\
\hline & & Layout & 5 & VE \\
\hline \multirow[t]{2}{*}{2.} & Format & Writing & 5 & VE \\
\hline & & Layout & 5 & VE \\
\hline \multirow[t]{2}{*}{3.} & Organization & Presentation & 5 & VE \\
\hline & & Ease of use & 4,5 & VE \\
\hline \multirow[t]{5}{*}{4.} & Attractiveness & Cover design & 4 & E \\
\hline & & Content design & 5 & VE \\
\hline & & Colour & 5 & VE \\
\hline & & Interests and motivation & 5 & VE \\
\hline & & Image display quality & 5 & VE \\
\hline \multirow[t]{2}{*}{5.} & Alphabet & Font type & 5 & VE \\
\hline & & Font size & 5 & VE \\
\hline \multirow[t]{2}{*}{6.} & Empty space & Use of free space & 5 & VE \\
\hline & Mean & & 4,89 & VE \\
\hline
\end{tabular}

The result of converting the product rating scale score by media experts is 4.89 with very eligible criteria. The media expert also give advice for the media revision. The first piece of advice is on the title page, information should be added about the target user (for what class this media is used) and under the name of the student, the name of the study program should be written. Besides that, the media expert recommend that the media be given a page number identity.

Test Product Validation by Material Experts

The initial product of the story calendar media was tested for validation by material experts in order to determine the feasibility level of the material quality and its suitability for grade IV SD students. Below is a table of the results of the product rating scale by material experts.

Table 3. Product Rating Scale Results by Material Experts

\begin{tabular}{cllcc}
\hline No. & \multicolumn{1}{c}{ Aspects } & \multicolumn{1}{c}{ Indicators } & Mean Score & Criteria \\
\hline 1. & Substance & Suitability of material with learning objectives & 4 & $\mathrm{E}$ \\
& & The suitability of the story with student characteristics & 4,7 & VE \\
2. & The level of & Clarity of competencies that students must achieve & 4,5 & VE \\
& importance in & Ease of material to understand & 4,75 & VE \\
& learning & The breadth and depth of the material & 4 & $\mathrm{E}$ \\
& & Teacher and student interactivity in learning & 4 & $\mathrm{E}$ \\
3. & Narrative elements & 5 & VE \\
& & Plot & 4,7 & VE \\
& Figures and characterizations & 5 & VE \\
& Setting & 4,3 & VE \\
& Tema & 5 & VE \\
4. & Usefulness & Conflict & 5 & VE \\
& Benefits for students & 5 & VE \\
& Mean & Benefits for teachers & 4,61 & VE \\
\hline
\end{tabular}

The result of the conversion of the product rating scale score by material experts is 4.61 with very eligible criteria. Advice from material experts, the first is instructions for use must be operational to what teachers and students are doing. The second piece of advice is the product description must 
describe the contents of the product. And the third is the setting needs to be clarified. The fifth piece of advice is several values of the character of responsibility need to be strengthened.

Test Product Validation by Linguists

The initial product of the story calendar media was tested for validation by linguists to know the level of feasibility of language quality and its suitability for grade IV SD students. Table 4 is the results of the product rating scale by linguists.

Table 4. Table of Product Rating Scale Results by Linguists

\begin{tabular}{|c|c|c|c|c|}
\hline No. & Aspects & Indicators & Mean Score & Criteria \\
\hline \multirow[t]{4}{*}{1.} & Language & Language conformity with EYD & 4 & $\mathrm{E}$ \\
\hline & Conformity & $\begin{array}{l}\text { Suitability of the language used (communicative/easy to } \\
\text { understand) }\end{array}$ & 5 & VE \\
\hline & & The sentences used are not biased & 5 & VE \\
\hline & & The effectiveness of the sentences used & 4 & $\mathrm{E}$ \\
\hline \multirow[t]{5}{*}{2.} & Use of Language & Clarity of meaning of words & 4 & $\mathrm{E}$ \\
\hline & & Word selection accuracy & 4 & $\mathrm{E}$ \\
\hline & & Clarity of sentences & 5 & VE \\
\hline & & The charm of style & 5 & VE \\
\hline & & The accuracy of using foreign terms & 5 & VE \\
\hline \multirow[t]{7}{*}{3.} & Language & Letter clarity & 4 & $\mathrm{E}$ \\
\hline & Readability & Clarity of symbols / punctuation & 5 & VE \\
\hline & & Clarity of command/ instruction sentences & 4 & VE \\
\hline & & Ease of reading comprehension & 5 & VE \\
\hline & & Reading text wrinkles & 5 & VE \\
\hline & & Language compatibility with supporting images & 4 & $\mathrm{E}$ \\
\hline & & Mean & 4,53 & VE \\
\hline
\end{tabular}

The result of converting the product rating scale score by linguists is 4.53 with very eligible criteria. Advice from linguists: (1) pay attention and check the writing system, especially punctuation marks and writing foreign words. (2) pay attention and check the accuracy of diction and use of the word assignment.

Based on the assessment of media experts, material experts, and linguists, the story calendar media product is declared very eligible and ready to be used for research by considering the suggestions of experts. After being tested by experts and receiving input, the product is revised and printed until it is ready to be tested in the field.

\section{Preliminary Field Testing}

The initial field test was carried out at SD Negeri 2 Srandakan. The subjects in this trial were 9 grade IV students and 1 grade IV teacher. The trial was carried out on a limited face-to-face basis due to the pandemic situation. Learning is carried out by adhering to health protocols in wearing masks, maintaining distance, and washing hands before and after activities. The initial field test was carried out on October 27, 2020.

In this trial, students and teachers carried out learning using story calendar media. The teacher uses an A3 size media story calendar and tells the story of the 1st day entitled "Tanggung Jawab Saat Sakit". Students listen using story calendars in the form of a sitting calendar that each student holds. Students also pay attention to writing in stories related to the use of capital letters and punctuation. After listening to the story, students find the elements of a narrative essay and write them down on a mind map. The mind map will later become a tool for students to make it easier to rewrite the story.

After compiling the mind map, students rewrite Tanggung Jawab Saat Sakit's content in their own language. Of course, by paying attention to good and correct writing. The teacher checks the student's work while reminding them of the completeness of narrative essays and writing procedures.

After finishing the lesson, the teacher is asked to fill in a response scale, and students are asked to fill out a response questionnaire to the story calendar media. Below is a table of the results of the teacher response scale. 
Jurnal Prima Edukasia, 9 (2), 2021 - 207

Tri Astuti Rokhmani, Suhardi Suhardi

Table 5. Results of the Response Scale for Class IV Teachers at SD Negeri 2 Srandakan

\begin{tabular}{clcc}
\hline No. & \multicolumn{1}{c}{ Indicators } & Mean Score & Criteria \\
\hline 1. & Conformity with the character being developed & 5 & VE \\
2. & The suitability of the story calendar media with the learning objectives & 5 & VE \\
3. & Clarity of study instructions & 4,3 & VE \\
4. & The breadth and into the material & 5 & VE \\
5. & Suitability with student characteristics & 5 & VE \\
6. & Suitability with student characteristics & 5 & VE \\
7. & Narrative text quality & 4,75 & VE \\
8. & Media display quality & 4,8 & VE \\
9. & Overall physical appearance criteria for the media & 4,6 & VE \\
\multicolumn{2}{r}{ Mean } & 4,83 & VE \\
\hline
\end{tabular}

The results of the teacher response scale conversion obtained a score of 4.83 with very good criteria. The teacher's suggestions are: (1) the order of the characters' names in narrative story 1 should be adjusted to the order in the illustration. (2) in the instructions for use number 1, the narrative composition (meaning and elements) can be elaborated.

Based on the conversion of the teacher response scale scores and the student response questionnaire, it appears that the story calendar media is declared very eligible, with responses from 9 students stating "Yes" in all statements. Thus, the story calendar media can be used for field trials by revising it according to input.

\section{Main Product Revision}

The input obtained from the student and teacher response questionnaires from the initial field test was used to revise the story calendar product. Researchers refine the story calendar that has passed the initial field-testing stage to produce the main product for field trials.

\section{Main Field Testing}

Field trials were carried out at SD Negeri 1 Srandakan. The subjects in this trial were 18 grade IV students (9 each from classes A and B) and 2 grade IV teachers from grades A and B. The trial was carried out in a limited face-to-face due to the pandemic situation. Learning is carried out by adhering to health protocols in wearing masks, maintaining distance, and washing hands before and after activities. Field trials were held on November 4, 2020.

In this trial, students and teachers carried out learning using story calendar media. The teacher uses an A3 size media story calendar and tells the story of the 1st day entitled "Tanggung Jawab Saat Sakit'. Students listen using story calendars in the form of a sitting calendar that each student holds. Students also pay attention to writing in stories related to the use of capital letters and punctuation. After listening to the story, students find the elements of a narrative essay and write them down on a mind map. The mind map will later become a tool for students to make it easier to rewrite the story.

After compiling the mind map, students rewrite the content of the story in their own language. Of course, by paying attention to good and correct writing. The teacher checks the student's work while reminding them of the completeness of elements of narrative essays and writing procedures.

After finishing the lesson, the teacher is asked to fill in a response scale, and students are asked to fill out a response questionnaire to the story calendar media. Below are the results of the teacher response scales for grades IV $\mathrm{A}$ and IV $\mathrm{B}$.

Table 6. Results of the Response Scale for Class IV A Teachers at SD Negeri 1 Srandakan

\begin{tabular}{clcc}
\hline No. & \multicolumn{1}{c}{ Indicators } & Mean Score & Criteria \\
\hline 1. & Conformity with the character being developed & 5 & VE \\
2. & The suitability of the story calendar media with the learning objectives & 5 & VE \\
3. & Clarity of study instructions & 4 & VE \\
4. & Breadth and into the material & 4,5 & VE \\
5. & Suitability with student characteristics & 5 & VE \\
6. & Completeness of the elements of the story & 5 & VE \\
7. Narrative text quality & 5 & VE \\
8. & Media display quality & 5 & VE \\
9. & Overall physical appearance criteria for the media & 4,8 & VE \\
& & 4,81 & VE \\
\hline
\end{tabular}


Jurnal Prima Edukasia, 9 (2), 2021 - 208

Tri Astuti Rokhmani, Suhardi Suhardi

Table 7. The results of the response scale of grade IV B teachers at SD Negeri 1 Srandakan

\begin{tabular}{clcc}
\hline No. & \multicolumn{1}{c}{ Indicators } & Mean Score & Criteria \\
\hline 1. & Conformity with the character being developed & 5 & VE \\
2. & The suitability of the story calendar media with the learning objectives & 5 & VE \\
3. & Clarity of study instructions & 4 & VE \\
4. & The breadth and into the material & 4,5 & VE \\
5. & Suitability with student characteristics & 5 & VE \\
6. Completeness of the elements of the story & 5 & VE \\
7. Narrative text quality & 5 & VE \\
8. & Media display quality & 5,8 & VE \\
9. Overall physical appearance criteria for the media & Mean & 4,81 & VE \\
\hline
\end{tabular}

The results of the conversion of the teacher response scale from class A teachers were 4.81 (very eligible criteria) and class B teachers, namely 4.81 (very eligible criteria). As for the advice from the teacher, namely: the instructions for using the story calendar media, the steps should be clarified.

Based on the conversion of the teacher response scale scores and the student response questionnaire, it appears that the story calendar media is declared very eligible with the responses of 17 students stating "Yes" in all statements and one student stating "No" in the statement "Instructions for using calendar media the story is easy to understand". Thus, the story calendar media can be used for operational field testing by revising it according to input.

\section{Operational Product Revision}

Inputs obtained from student and teacher response questionnaires from field trials are used to revise the story calendar product. Researchers perfect the story calendar that has passed the initial field test stage to produce the main product for operational field testing.

\section{Discussion}

This study aimed to develop an eligible story calendar media. According to USAID/Indonesia (2014), a story calendar arrangement of several sheets of paper containing messages or teaching materials that are neatly arranged and made like a calendar. The paper on the story calendar contains a different activity each day. Activities with a story calendar make it easier for students to understand stories and write narrative essays. Hermanto and Anisyah (2017) say that story calendars with character values can be used as a strategy to strengthen mental revolution because they try to instil a supporting character for mental revolution in elementary school students. In addition to developing character, story calendar media was also developed to improve students' writing skills, especially narrative writing skills. That condition because that the development of writing skills is one of the components of any language teaching curriculum, regardless of the student's particular field of study (Rus, 2016). Therefore, before being used in learning, the story calendar media must be tested for its eligibility first.

The appropriateness of the story calendar media product as a source of supporting literacy to improve narrative writing skills and the responsibility character of fourth-grade elementary school students is based on product assessments by media experts, material experts, and linguists. In addition to providing a product quality rating on a scale, experts also provide comments and suggestions for media story calendars. The comments and suggestions serve as a guide for improving the story calendar media product so that it is ready to be tested in the field.

The media expert's assessment of the story calendar media includes aspects of consistency, format, organization, attractiveness, letters, and empty space. The assessment results get an average score of 4.89 , and after being converted, it is in the "very eligible" category. The design of the story calendar media is arranged in such a way as to attract students' interest with the function of achieving the goal of improving narrative writing skills and the character of responsibility of fourth-grade elementary school students. The media layout is designed with colours, illustrations and is well laid out and adapted for elementary students. Utomo (2018) said that the developed illustrated storybooks contain word choice, language, story, and colour combination, which are adjusted to the characteristics of students. This makes the students become more enthusiastic about learning. Ulfah and Soenarto (2017) also said that learning media is needed to support students' interest in being fond and proficient in writing both fiction and non-fiction stories. Image media has a positive and significant effect on story content 
Jurnal Prima Edukasia, 9 (2), 2021 - 209

Tri Astuti Rokhmani, Suhardi Suhardi

rewriting skills. Azmussya'ni and Wangid (2014) found through their research that (1) the use of image media can motivate students to learn happily, freely, actively, and productively, so that psychological obstacles that hinder students can be resolved; (2) the intensity of writing skills students are increasing, that is, from less fluent writing becomes smooth and easy; (3) the results of students' writing skills are getting increases, the neatness of writing is getting better, correct spelling and punctuation; (4) students are trained in various things, or experiences, such as daring to express opinions and willing to accept differences of opinion as well dare to display their work on front of the class; (5) the teacher changes the function of a conveyor of knowledge to becoming facilitator, dynamist and motivator.

The material expert's assessment of the story calendar media includes aspects of substance, level of importance in learning, narrative elements, and usefulness. After being assessed by material experts, the story calendar media product got an average score of 4.61, and after being converted, it was included in the "very eligible" category. The media content of the story calendar basically contains short material about the narrative and the character of responsibility, six narrative stories with the theme of responsibility, and an assignment to analyze the elements of the narrative and then rewrite the contents of the story. The story calendar contains narrative pictures and stories. Wilson and Glazier (2014) states that narration tells the reader a story. An effective narrative allows the reader to experience an event with the author. The purpose of the narrative is to invite the reader to experience the author's experience. The experience that is conveyed through the narrative in the media story calendar has the theme of responsibility. Violetta (2015) say that media in the form of literature containing stories can add to one's experience of responsibility. Based on this opinion, it can be interpreted that the media containing stories can develop the character of student responsibility in this form of narrative. The content of these characters is contained in the contents of the story presented. The media in the form of literature in this study is manifested in a story calendar media that contains narrative stories with a load of responsibility characters.

The story calendar media product also contains an assignment in the form of analyzing the elements of a narrative essay and then writing it down on a mind map. One of the points in the student response questionnaire reads, "making a mind map makes it easier for me to rewrite the contents of the story". All students in the test subject stated "Yes" to the statement. This is supported by Satini (2016) opinion, which states that using the mind map technique can improve students using writing that provides understanding and knowledge in writing exposition of qualifications that are more than sufficient to be good qualifications. In developing this media, mind maps are used to make it easier for students to write narrative essays. In his research findings, Wette (2017) also stated that a mind map is a useful means for advancing students' development of genre knowledge and providing them with opportunities for reflection. Thinking processes involved in map construction can also facilitate important learning processes that include metacognitive awareness development, the reframing of schematic relationships and meanings (Kolb, 2015). Making a mind map will be easier for students to organize the ideas to be written.

Meanwhile, the story calendar media product also received an assessment from a linguist with the aim of knowing the feasibility of language quality and its suitability for fourth-grade elementary school students. The aspects assessed include language suitability, language use, and language readability. The results of the expert's assessment got an average score of 4.53 in the "very eligible" category. Language suitability, usage and readability are important in a product developed for elementary students. This is related to the ease of capturing and understanding the content of the reading. Thus, it will positively impact subsequent assignments that aim to improve narrative writing skills and character responsibility.

A recent meta-analysis on the effects of reading interventions on writing (Graham \& Harris, 2017) found that reading instruction strengthened writing skills and that effects were maintained over time. The effects of reading interventions on writing were seen in many areas of writing, including spelling, words written, writing quality, and an overall measure of writing. A recent study found similar practices in a Norwegian context (Blikstad-Balas et al., 2018). The results from this study show that basic writing skills likely support reading skills in young learners. Hence it underscores the importance of explicit teaching of all aspects of writing as an important part of literacy instruction. Williams and Larkin (2013) said, in summary, it seems that reading fluency may have a particular association with the number of written texts children produced.

The categories of product assessment results by experts are adjusted to the conversion table proposed by Widoyoko (2015). Overall, based on the assessment of media experts, material experts, and 
linguists, the story calendar is in the "very eligible" category. The story calendar media products that have been assessed by experts and declared appropriate are then corrected according to comments and suggestions from each expert. After being repaired, the story calendar media is ready to be tested in the field, in this case, in learning in elementary schools.

Sari and Syamsi (2015) said that the implementation of thematic-integrative learning must pay attention to the development of character values and the development of students' attitudes. The 2013 curriculum, which is now being applied in Indonesia, views that the development of attitudes is emphasized because students will become the next generation of the nation who are expected to have individuals with noble characters. One of the characters developed is the character of responsibility.

Apriani and Wangid (2015) support this opinion by stating that thematic-integrative learning is important because it can improve students' soft skills and hard skills based on their active, interesting, and meaningful learning process. The statement also means that thematic-integrative learning provides great opportunities for teachers to develop three competencies, namely knowledge, attitudes, and skills, that lead to a human person who has a good character.

Based on the above opinion, the story calendar media is suitable to be used as a medium to improve students' hard skills and soft skills. In this case, namely, narrative writing skills as hard skills and responsibility characters as soft skills. The use of media in learning is indeed important. Pingge and Wangid (2016) says that learning media in teaching and learning activities will help teachers and students achieve learning goals as proven by satisfactory learning outcomes. Because in broad outline, there are three parts to learning media goals: motivating, conveying information, and instructional objectives. Motivational goals to entertain and arouse students' interest. Informational objectives are usually used to present information, in this case conveying learning material. Instructional objectives are intended to foster the interest given through the psychological involvement of students or other activities related to the learning media used. Odera (2011) states that the use of technology and learning media are expected to motivate the students during the learning process. Media has a strong influence on the learning process.

Based on the assessment of experts, teachers, and students, the media story calendar is relevant to motivate students in learning from the aspects of media, material, and language. Gonen et al. (2012) I suggested that the teachers choose the books that get to the children skills of life-wide thinking and using learned skills in daily life. The story calendar media can be chosen as an alternative to books that contain stories of everyday life and contextual learning for students to learn to write narratives and character responsibilities.

Based on the results of the assessment of the story calendar media product by experts and the results of the teacher and student response questionnaires during the trial, it can be concluded that the story calendar media is feasible and is supported by relevant theories. Thus, this story calendar media product can be used as a source of supporting literacy in learning to improve narrative writing skills and the character of responsibility for fourth-grade elementary school students.

\section{Conclusion}

Based on the media development results that have been performed above, it can be concluded that the story calendar media "Hebatnya Bertanggung Jawab" are ready for implementation. The validity is proven by the validators, consisting of the media expert, material expert, language expert, and the teachers and students' responses. The mean score from the expert and teachers responses belongs to the "Very Eligible" criteria. All the student's responses showed that they said "Yes" almost 100\% in all the statements from the student's questionnaire.

It is expected that the story calendar media "Hebatnya Bertanggung Jawab" can serve as an alternative to literacy media and supplementation learning material, especially for writing skills learning and developing student's responsibility character of grade four elementary school students. It can be implemented and get the benefit of it. In addition, the hope is that story calendar media can be developed and innovated by teachers with objectives, themes, and other materials relevant to elementary school students' learning. For the next research, the effectiveness of this media for writing skill learning and developing student's responsibility character is needed. 
Jurnal Prima Edukasia, 9 (2), 2021 - 211

Tri Astuti Rokhmani, Suhardi Suhardi

\section{Acknowledgement}

Researchers would like to thank the Directorate of Research and Community Service, Ministry of Research, Technology and Higher Education, to provide the opportunity and funding for this research.

\section{References}

Ahn, H. (2012). Teaching writing skills based on a genre approach to 12 primary school students: an action research. English Language Teaching, 5(4), 1-16.

Ambarwati, W., \& Budiningsih, C. A. (2018). The effectiveness of video and deck card use in crafting the skills of writing experience within the elementary school students. Jurnal Prima Edukasia, 6(2), 177-188. https://doi.org/10.21831/jpe.v6i2.9781

Apriani, A.-N., \& Wangid, M. N. (2015). Pengaruh SSP tematik-integratif terhadap karakter disiplin dan tanggung jawab siswa kelas III SD. Jurnal Prima Edukasia, 3(1), 12-25. https://doi.org/10.21831/JPE.V3I1.4061

Azmussya'ni, A., \& Wangid, M. N. (2014). Peningkatan keterampilan menulis menggunakan pendekatan proses dengan media gambar di SDN 3 Sakra. Jurnal Prima Edukasia, 2(1), 1. https://doi.org/10.21831/jpe.v2i1.2640

Blikstad-Balas, M., Roe, A., \& Klette, K. (2018). Opportunities to write: an exploration of student writing during language arts lessons in norwegian lower secondary classrooms. Written Communication, 35(2), 119-154. https://doi.org/10.1177/0741088317751123

Borg, W. R., \& Gall, M. D. (1983). Educational research: An introduction. Longman.

Gonen, M., Aydos, E. H., \& Erturk, H. G. (2012). Social skills in pictured story books. Procedia Social and Behavioral Sciences, 46, 5280-5284. https://doi.org/10.1016/j.sbspro.2012.06.422

Graham, S., \& Harris, K. R. (2017). Reading and writing connections: How writing can build better readers (and vice versa). In Improving Reading and Reading Engagement in the 21 st Century (pp. 333-350). Springer Singapore. https://doi.org/10.1007/978-981-10-4331-4_15

Hermanto, R., \& Anisyah, A. (2017). Media literasi kalender cerita bermuatan nilai karakter sebagai strategi penguatan revolusi mental bagi siswa sekolah dasar kelas rendah. Proceeding ICoLLiT (International Conference on Language, Literature and Teaching), 860-869. http://hdl.handle.net/11617/8940

Johnson, A. P. (2008). Teaching reading and writing. Rowman and Littlefield Education.

Kolb, D. A. (2015). Experimental learning: experience as the source of learning and development. Pearson.

Odera, F. Y. (2011). Motivation: The most ignored factor in classroom instruction in Kenyan secondary schools. International Journal of Science and Technology, 1(6), 283-288.

Pingge, H. D., \& Wangid, M. N. (2016). Faktor yang mempengaruhi hasil belajar siswa sekolah dasar di kecamatan Kota Tambolaka. Jurnal JPSD (Jurnal Pendidikan Sekolah Dasar), 2(2), 107 122. https://doi.org/10.12928/jpsd.v2i2.4947

Rachman, D., Soviyah, S., Fajaruddin, S., \& Pratama, R. A. (2020). Reading engagement, achievement and learning experiences through kahoot. LingTera, 7(2). https://doi.org/10.21831/lt.v7i2.38457

Rus, D. (2016). A didactic approach to writing skills in a technical learning environment. Procedia Technology, 22, 1191-1196. https://doi.org/10.1016/j.protcy.2016.01.167

Sari, I. P., \& Syamsi, K. (2015). Pengembangan buku pelajaran tematik-integratif berbasis nilai karakter disiplin dan tanggung jawab di sekolah dasar. Jurnal Prima Edukasia, 3(1), 73-83. https://doi.org/10.21831/JPE.V3I1.4070

Satini, R. (2016). Kemampuan menulis karangan eksposisi dengan menggunakan teknik mind map siswa kelas X SMA Negeri 14 Padang. Gramatika STKIP PGRI Sumatera Barat, 2(2), 164-178. https://doi.org/10.22202/jg.2016.v2i2.976

Tompkins, G. E. (2015). Language arts: Patterns of practice (9th ed.). Pearson.

Ulfah, D. M., \& Soenarto, S. (2017). Pengaruh penggunaan media video dan gambar terhadap 
Jurnal Prima Edukasia, 9 (2), 2021 - 212

Tri Astuti Rokhmani, Suhardi Suhardi

keterampilan menulis kelas V. Jurnal Prima Edukasia, 5(1), 22-34.

https://doi.org/10.21831/jpe.v5i1.7693

USAID/Indonesia. (2014). Pembelajaran literasi kelas awal SD/MI di LPTK. RTI International.

Utomo, F. B. B. (2018). Developing illustrated story books to improve beginning reading skills and learning motivation. Jurnal Prima Edukasia, 6(2), 118-128. https://doi.org/10.21831/jpe.v6i2.16456

Violetta-Irene, K. (2015). The use of literature in the language classroom: Methods and aims. International Journal of Information and Education Technology, 5(1), 74-79. https://doi.org/10.7763/IJIET.2015.V5.479

Wette, R. (2017). Using mind maps to reveal and develop genre knowledge in a graduate writing course. Journal of Second Language Writing, 38, 58-71. https://doi.org/http://dx.doi.org/10.1016/j.jslw.2017.09.005

Widoyoko, S. E. P. (2015). Evaluasi program pembelajaran: panduan praktis bagi pendidik dan calon pendidik (Cet. ke-3). Pustaka Pelajar. https://doi.org/2013

Williams, G. J., \& Larkin, R. F. (2013). Narrative writing, reading and cognitive processes in middle childhood: What are the links? Learning and Individual Differences, 28, 142-150. https://doi.org/10.1016/j.lindif.2012.08.003

Wilson, P., \& Glazier, T. F. (2014). The least you should know about English: Writing skills, (11th ed.). Wadsworth Cengage Learning. 